\title{
20 years at campus: heritage assessment update for Somosaguas fossil geosite (Pozuelo de Alarcón, Madrid)
}

\author{
Lucía R. SUALDEA ${ }^{1 *}$, Adriana OLIVER ${ }^{2}$, Fernando BLANCO ${ }^{3}$, Iris MENÉNDEZ ${ }^{1,4}$, Manuel \\ HERNÁNDEZ FERNÁNDEZ ${ }^{1,4}$, Laura DOMINGO ${ }^{1,5}$ \& Ana Rosa GÓMEZ CANO ${ }^{6,7}$
}

${ }^{1}$ Departamento de Geodinámica, Estratigrafía y Paleontología, Facultad de Ciencias Geológicas, Universidad Complutense de Madrid, C/ José Antonio Novais 12,28040, Madrid; lurodr06@ucm.es, irismene@ucm.es, hdezfdez@ucm.es, ldomingo@ucm.es.

${ }^{2}$ Geosfera, C/ Madres de la Plaza de Mayo, 2, 28523, Rivas-Vaciamadrid, Madrid; aoliverp5@gmail.com

${ }^{3}$ Museum für Naturkunde, Leibniz-Institut für Evolutions und Biodiversitätsforschung, Invalidenstraße 43, 10115, Berlin, Germany; fernando.blanco@mfn.berlin

${ }^{4}$ Departamento de Geología Sedimentaria y Cambio Medioambiental, Instituto de Geociencias IGEO (CSIC, UCM), C/ Dr. Severo Ochoa, 7, 28040, Madrid

${ }^{5}$ Earth and Planetary Sciences Department. University of California Santa Cruz, 1156 High Street, 95064, Santa Cruz, USA

${ }^{6}$ Transmitting Science, C/ Gardenia 2, Piera, 08784, Barcelona.

${ }^{7}$ Institut Català de Paleontologia Miquel Crusafont, Edifici ICP, Campus de la UAB s/n, 08193, Cerdanyola del Vallès; argomezcano@gmail.com

* Corresponding author

Sualdea, L.R., Oliver, A., Blanco, F., Menéndez, I., Hernández Fernández, M., Domingo, L. \& Gómez Cano, A.R. 2019. 20 years at campus: heritage assessment update for Somosaguas fossil geosite (Pozuelo de Alarcón, Madrid). [20 años en el campus: actualización de la valoración patrimonial del yacimiento paleontológico de Somosaguas (Pozuelo de Alarcón, Madrid)]. Spanish Journal of Palaeontology, 34 (1), 121-124.

Manuscript received 5 February 2019

Manuscript accepted 16 May 2019 https://doi 10.7203/sjp.34.1.15253

(C) Sociedad Española de Paleontología ISSN 2255-0550

\section{ABSTRACT}

The palaeontological heritage evaluation of the Somosaguas fossil geosite has been revised on the basis of scientific and sociocultural criteria. By means of this study have been proposed four new criteria that arise from new scientific and social trends as well as technological advances. A temporal comparison has been established with previous evaluations obtained in the years 2000 and 2012. The results indicated an increase in the initial score of the geosite in each revision. Our study shows the relevance of palaeontological heritage evaluations as useful tools to improve fossil geosites management.

Keywords: Palaeontological heritage, heritage evaluation, dissemination, fossil geosites, Miocene.

\section{RESUMEN}

Se ha revisado la valoración patrimonial del yacimiento paleontológico de Somosaguas en función de criterios científicos y socioculturales, proponiendo cuatro nuevos criterios surgidos tanto de las nuevas tendencias científicas y sociales como de los avances tecnológicos. Se ha establecido una comparación entre la valoración actual y las valoraciones obtenidas en los años 2000 y 2012. Los resultados obtenidos indican un aumento de la puntuación inicial del yacimiento en cada una de las revisiones. Nuestro estudio muestra la importancia de las valoraciones patrimoniales paleontológicas como herramientas útiles en la gestión de yacimientos paleontológicos.

Palabras clave: Patrimonio paleontológico, valoración patrimonial, divulgación, yacimientos paleontológicos, Mioceno. 


\section{INTRODUCTION}

The Somosaguas fossil geosite is in Pozuelo de Alarcón (Madrid, Spain). One of the peculiarities of this geosite is their location within the campus of the Universidad Complutense de Madrid (UCM) (Fig. 1). It has been excavated every year since 1998 by bachelor and master students and researchers. Multidisciplinar works in this geosite include: a) stratigraphy, sedimentology and mineralogical composition of rock host of the fossil geosite; b) systematics and taxonomy of the fossils found there; and c) biochronology, palaeoecology, taphonomy and palaeobiogeography of the vertebrate fauna (Domingo et al., 2017; Menéndez et al., 2017; and references therein).

During this time, a total of 24 mammal species have been identified and described (Hernández Fernández et al., 2006). Moreover, from the palaeoclimatic standpoint, this geosite is particularly interesting because it was contemporaneous with the cooling event that took place immediately after the Middle Miocene Climatic Optimum as a consequence of the reestablishment of the ice cap in Eastern Antarctica (Flower \& Kennett, 1994; Zachos et al., 2001; Lewis et al., 2008; Domingo et al., 2009). Recently the Somosaguas fossil geosite has been included in the catalogue of Places of Geological Interest.

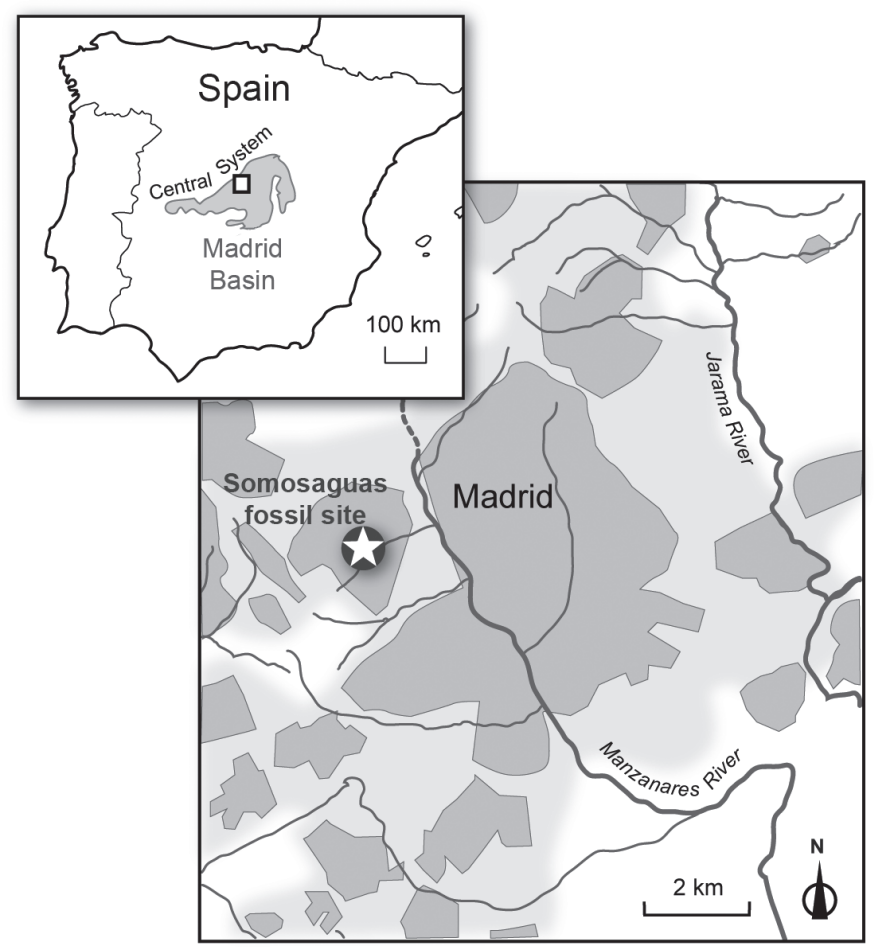

Figure 1. Location of Somosaguas fossil geosites (marked with a star) within the Iberian Peninsula and near the city of Madrid. Modified from García Yelo et al. (2014).
There were two previous geoheritage assessments of the fossil geosite, the first carried out by Gómez \& Morales (2000), barely two years after the start of the excavations, and the second carried out by Hernández Fernández et al. (2012). Since the year 2018 supposed the 20th anniversary of the beginning of activities at the Somosaguas geosite, this work represents an update of the assessment of this fossil geosite. Moreover, after this revision we propose new criteria to be included in future heritage reviews that would include not only the scientific interest of the fossil geosite (as previous criteria rated), but also the academic and dissemination interest of target audiences through different media.

\section{METHODS}

We performed an assessment on the basis of 15 previously proposed criteria (Gómez \& Morales, 2000), scored from 0 to 2, and divided into scientific and sociocultural categories. We compared the scores obtained for the same fossil geosite in the years 2000 and 2012 (Gómez \& Morales, 2000; Hernández Fernández et al., 2012) and re-evaluated the fossil geosite taking into account the state and activities performed until January 2018.

There is a latest method for the fossil geoheritage, which is accepted and tested by the Spanish geoconservationist community proposed by the Instituto Geológico y Minero de España (IGME) (available at www.igme.es/patrimonio/ novedades/METODOLOGIA\%20IELIG\%20web.pdf). Nevertheless, we use for this work the previous method (Gómez \& Morales, 2000) in order to compare the results across time for the $20^{\text {th }}$ anniversary of this fossil site. Next works will be developed in order to evaluate the Somosaguas fossil site under the criteria developed with the latest method.

Additionally, we considered necessary to add new assessment criteria to both scientific and sociocultural categories.

\section{$\underline{\text { Scientific category. }}$}

a) Scientific publications. Scores: 0 (no publications), 1 (one publication) and 2 (more than two publications).

b) Contributions to scientific meetings. Scores: 0 (no contributions), 1 (contributions to national meetings) and 2 (contributions to international meetings).

Sociocultural category. It is important to divide the touristic and educational interest into two different criteria. On the one hand, we describe a criteria named "Didactic interest", and on the other hand, a second one named "Outreach interest". Moreover, we also create two new criteria within this section in order to highlight the impact of the works carried out on the fossil geosites in different media. 
a) Didactic interest. Scores: 0 (no didactic interest), 1 (it is linked to an academic institution), 2 (activities are offered within the curriculum of an academic institution -offering credits to students who participate in work related to the geosite-).

b) Outreach interest. Scores: 0 (no outreach interest), 1 (passive means of dissemination: visitors can find information boards and can create a self-guided visit), 2 (active means of dissemination: open doors days and guided tours are carried out systematically).

c) Repercussion in conventional media (television, press and radio). Scores: 0 (there are no news in these media), 1 (there are news, but they are exceptional), 2 (in addition to news, a monographic documentary has been made).

d) Internet repercussion. Scores: 0 (it has not online presence), 1 (it has a social network or website and is active), 2 (it has active presence in all social networks and there is a website).

\section{RESULTS AND DISCUSSION}

The obtained results indicated a 3-point increase in the total evaluation with regard to 2012, only taking into account the Gómez \& Morales (2000) criteria. This variation does not seem to be very marked if we compare with the evaluations from the years 2000 and 2012 (Table 1). This is because in 2012 many of the evaluated criteria reached already its maximum punctuation.

On the other hand, the following criteria have increased their scores with respect to the last assessment (Hernández Fernández et al., 2012): a) macromammalian taxa: based on the description of the new suid Retroporcus complutensis (Pickford \& Laurent, 2014) species; b) type locality: due to the description of this new suid species (Pickford \& Laurent, 2014); and, c) the association with other heritage places: since 2016, the Somosaguas fossil geosites part of the catalogue of Places of Geological Interest elaborated by the Geological and Mining Institute of Spain.

It is important to note that, since 2012, specific actions have been undertaken on different criteria that had already reached the highest score. Some examples are: identification of a new species of micromammal, new publications on taphonomy and palaeoecology of the geosite, an increase in the number of fossils in the collection, installation of walkways and fences that improve visiting conditions, and placement of permanent informative boards.

Finally, applying the new criteria proposed in this work, the heritage evaluation of Somosaguas increased by 8 points. This increase reflects the improvement in the management of the fossil geosite and the relevance of the evaluations. Future assessments will allow us to keep tracking the results of the actions taken based on previous results.

Table 1. Geoheritage assessment of the Somosaguas fossil geosite. New criteria for the evaluation of Palaeontological fossil geosites are marked in bold and italics.

\begin{tabular}{|c|c|c|c|c|c|c|c|}
\hline Sicentific criteria & 2018 & 2012 & 2000 & Sociocultural criteria & 2018 & 2012 & 2000 \\
\hline Large mammals & 2 & 1 & 1 & Historical singularity & 2 & 2 & 0 \\
\hline Small mammals & 2 & 2 & 1 & Association with other heritages & 1 & 0 & 0 \\
\hline Other fossils & 1 & 1 & 0 & Extension & 2 & 2 & 2 \\
\hline Type Locality & 2 & 1 & 0 & Accesibilidad & 2 & 2 & 1 \\
\hline Bioestratigraphic interest & 1 & 1 & 1 & Didactic interest/Turistic & $(2)$ & 2 & 1 \\
\hline Geological interest & 1 & 1 & 1 & Didactic interest & 2 & - & - \\
\hline Taphonomic interest & 2 & 2 & 1 & Outreach interest/turistic & 2 & - & - \\
\hline State of preservation & 1 & 1 & 0 & Projects & 2 & 2 & 1 \\
\hline State of the collection & 2 & 2 & 0 & Tradicional media (Radio, TV, press) & 1 & - & - \\
\hline Scientific puplications & 2 & - & - & Internet repecusion & 1 & - & - \\
\hline Contributions to scientific meetings & 2 & - & - & & & & \\
\hline
\end{tabular}

Total criteria (Gómez \& Morales, 2000) $\quad 25 \quad 22 \quad 10$

Total (new criteria included, this work) $\quad 33 \quad-\quad-$ 


\section{CONCLUSIONS}

The evaluation of Geosites of paleontological interest with the proposed methodology enables quantifying and establishing comparisons among different geosites. Moreover, the assessment permits to know which are the points that need to be improved. In the case of the Somosaguas fossil geosite, we have also established a temporal comparison of the scores obtained in 2000, 2012 and 2018. These evaluation criteria must be reviewed periodically paying attention to advances in scientific, social trends and technology. Finally, four new criteria are proposed that will allow us to highlight aspects of the geosites that arise from the advance of new technologies and scientific and social trends. These new assessment criteria revealed particularly important in order to maintain and facilitate the access of the palaeontological heritage to all audiences.

\section{ACKNOWLEDGEMENTS}

We deeply appreciate the work done by all the people involved within the Somosaguas project for 20 years. In particular, we would like to thank the pioneer and unconditional promoter of the project, Professor Nieves López Martínez (1949-2010). This is a contribution of Research Group UCM 910607 on Evolution of Cenozoic Mammals and Continental Palaeoenvironments (Complutense University of Madrid). ARGC is a member of the consolidated research group 2017 SGR 116 GRC of the Generalitat de Catalunya. IM was funded by a predoctoral grant from the Complutense University of Madrid (CT27/16-CT28/16). FB was funded by a research grant from Deutsche Forschungsgemeinschaft (LO 2368/1-1). This contribution has had partial funding from the Spanish Agencia Estatal de Investigación and the European Regional Development Fund of the European Union (CGL2017-82654-P, AEI/FEDER EU) and the Generalitat de Catalunya (CERCA Programme).

\section{REFERENCES}

Domingo, L., Cuevas-González, J., Grimes, S.T., Hernández Fernández, M. \& López-Martínez, N. 2009. Multiproxy reconstruction of the palaeoclimate and palaeoenvironment of the Middle Miocene Somosaguas site (Madrid, Spain) using herbivore dental enamel. Palaeogeography, Palaeoclimatology, Palaeoecology, 272, 53-68; doi: 10.1016/j.palaeo.2008.11.006.

Domingo, M.S., Martín-Perea, D., Domingo, L., Cantero, E., Cantalapiedra, J.L., García Yelo, B.A., Gómez Cano, A.R., Alcalde, G.M., Fesharaki, O. \& Hernández Fernández, M. 2017. Taphonomy of mammalian fossil bones from the debris-flow deposits of Somosaguas-North (Middle
Miocene, Madrid Basin, Spain). Palaeogeography, Palaeoclimatology, Palaeoecology, 465, 103-121; doi: 10.1016/j.palaeo.2016.10.023.

Flower, B.P. \& Kennett, J.P. 1994. The middle Miocene climatic transition: East Antarctic ice sheet development, deep ocean circulation and global carbon cycling. Palaeogeography, Palaeoclimatology, Palaeoecology, 108, 537-555; doi: 10.1016/0031-0182(94)90251-8.

García Yelo, B.A., Gómez Cano, A.R., Cantalapiedra, J.L., Alcalde, G.M., Sanisidro, O., Oliver, A., HernándezBallarín, V., López-Guerrero, P., Fraile, S. \& Hernández Fernández, M. 2014. Palaeoenvironmental analysis of the Aragonian (middle Miocene) mammalian faunas from the Madrid Basin based on body-size structure. Journal of Iberian Geology, 40, 129; doi: 10.5209/rev_JIGE.2014. v40.n1.44092.

Gómez, E. \& Morales, J. 2000. Inventario y valoración. In: Patrimonio Paleontológico de la Comunidad de Madrid (eds. Morales, J., Nieto, M., Amezua, L., Fraile, S., Gómez, E., Herráez, E., Peláez-Campomanes, P., Salesa, M.J., Sánchez, I.M. \& Soria, D.). Serie de la Consejería de Educación, Comunidad de Madrid, Madrid, 316-331.

Hernández Fernández, M., Cardaba, J.A., Cuevas-Gonzalez, J., Fesharaki, O., Salesa, M.J., Corrales, B., Domingo, L., Elez, J., López Guerrero, P., Sala-Burgos, N., Morales, J. \& López Martínez, N. 2006. The vertebrate sites of the Middle Miocene of Somosaguas (Pozuelo de Alarcón, Madrid): palaeoenvironmental and palaeoclimatic implications. Estudios Geológicos, 62, 263-294.

Hernández Fernández, M., Cantalapiedra, J.L., Cantero, E., Domingo, L., Yelo, B.G. \& Gómez Cano, A.R. 2012. Valoración patrimonial de los yacimientos del Mioceno medio de Somosaguas (Pozuelo de Alarcón, Madrid). Workshop "Aquello que nos faltó decirte": Homenaje a Nieves López Martínez. Miraflores de la Sierra (Madrid).

Lewis, A.R., Marchant, D.R., Ashworth, A.C., Hedenäs, L., Hemming, S.R., Johnson, J.V., Leng, M.J., Machlus, M.L., Newton, A.E., Raine, J.I., Willenbring, J.K., Williams, M. \& Wolfe, A.P. 2008. Mid-Miocene cooling and the extinction of tundra in continental Antarctica. Proceedings of the National Academy of Science, 105, 10676-10680; doi: 10.1073/pnas.0802501105.

Menéndez, I., Gómez Cano, A.R., García Yelo, B.A., Domingo, L., Domingo, M.S., Cantalapiedra, J., Blanco, F. \& Hernández Fernández, M. 2017. Body-size structure of Central Iberian mammal fauna reveals semidesertic conditions during the middle Miocene Global Cooling Event. PLOS ONE, 12: e0186762; doi: 10.1371/journal. pone.0186762.

Pickford, M. \& Laurent, Y. 2014. Valorisation of palaeontological collections: nomination of a lectotype for Conohyus simorrensis (Lartet, 1851), Villefranche d'Astarac, France, and description of a new genus of tetraconodont. Estudios Geológicos, 70, e002.

Zachos, J., Pagani, M., Sloan, L., Thomas, E. \& Billups, K. 2001. Trends, rhythms, and aberrations in global climate 65 Ma to present. Science, 292, 686-93; doi: 10.1126/ science. 1059412 . 